\title{
Nursing diagnoses, outcomes and interventions in the care of people with intestinal elimination stoma
}

\section{Diagnósticos, resultados e intervenções de enfermagem no cuidado às pessoas com estomia de eliminação intestinal}

\author{
Diagnósticos, resultados e intervenciones de enfermería en el cuidado de las \\ personas con estoma de eliminación intestinal
}

\author{
Carina Maris Gaspar Carvalho¹, Marcia Regina Cubas², Maria Miriam Lima da Nóbrega³
}

ORCID IDS

Carvalho CMG (D) http://orcid.org/0000-0003-2179-3049

Cubas MR (D http://orcid.org/0000-0002-2484-9354

Nóbrega MML (iD http://orcid.org/0000-0002-6431-0708
HOW TO CITE

Carvalho CMG; Cubas MR; Nóbrega MML. Nursing diagnoses, outcomes and interventions in the care of people with intestinal elimination stoma. ESTIMA, Braz. J. Enterostomal Ther., 16: e2218. doi: 10.30886/estima.v16.518.

Article from a doctoral thesis entitled Subset of ICNP® terminology, structured ontology, in the care of people with intesinal elimination stoma, Universidade Federal da Paraíba, 2017.

\begin{abstract}
Objectives: To create, on the basis of the International Classification of Nursing Practice (ICNP®), nursing diagnoses/outcomes and interventions statements in the care of people with intestinal elimination stoma and confirm, with specialists, the pertinence and relevance of the statements created. Methods: Methodological research developed from September 2016 to January 2017 , in which negative, positive, risk and chance nursing diagnoses/outcomes were created and statements of interventions for each diagnostic/ outcome. The diagnoses/outcomes and interventions created were mapped with the ICNP® version 2015, resulting in constant statements not included in the classification. The statements created and mapped were submitted to the process of confirmation of pertinence and relevance by 10 specialists, through a virtual questionnaire and data analysis by the percentage agreement method. Results: 110 nursing diagnoses/outcomes were created, of which 78 (70.9\%) were confirmed by specialists and 119 nursing interventions, of which 103 (86.5\%) were confirmed. Conclusion: the creation of statements of nursing diagnoses/outcomes and interventions and the process of confirmation of pertinence and relevance by specialists helped in the search for evidence of elements of nursing practice directed to the specific clientele.
\end{abstract}

DESCRIPTORS: Stoma; Nursing Process; Terminology; Stomatherapy.

\footnotetext{
${ }^{1}$ Universidade Federal da Paraíba - Centro de Ciências da Saúde - João Pessoa/PB - Brazil.

2Pontifícia Universidade Católica do Paraná - Escola Politécnica - Programa de Pós-Graduação em Tecnologia em Saúde - Curitiba/PR, Brazil. 3Universidade Federal da Paraíba - Centro de Ciências da Saúde - João Pessoa/PB - Brazil.

Corresponding author: Carina Maris Gaspar Carvalho | Rua José Antônio Leprevost, 50, apto. 33 | ZIP Code: 82640-070 - Curitiba/PR - Brazil | E-mail: carinacarvalho.cmgc@gmail.com

Received Aug. 112017 | Accepted Apr. 162018
} 


\section{RESUMO}

Objetivos: Construir, com base na Classificação Internacional para a Prática de Enfermagem (CIPE®), enunciados de diagnósticos/ resultados e intervenções de enfermagem no cuidado às pessoas com estomia de eliminação intestinal e confirmar, com especialistas, a pertinência e a relevância dos enunciados construídos. Métodos: Pesquisa metodológica desenvolvida no período de setembro de 2016 a janeiro de 2017, na qual foram construídos enunciados de diagnósticos/resultados de enfermagem negativos, positivos, de risco e de chance e enunciados de intervenções para cada diagnóstico/resultado. Os diagnósticos/resultados e intervenções construídos foram mapeados com a CIPE® versão 2015, resultando em enunciados constantes e não constantes da classificação. Os enunciados construídos e mapeados foram submetidos ao processo de confirmação de pertinência e relevância por 10 especialistas, por meio de questionário virtual e análise dos dados pelo método de porcentagem de concordância. Resultados: Foram construídos 110 diagnósticos/ resultados de enfermagem, dos quais 78 (70,9\%) foram confirmados pelos especialistas e 119 intervenções de enfermagem, das quais 103 (86,5\%) foram confirmadas. Conclusão: A construção de enunciados de diagnósticos/resultados e intervenções de enfermagem e o processo de confirmação de pertinência e relevância por especialistas auxiliaram na busca por evidências de elementos da prática de enfermagem direcionadas à clientela específica.

DESCRITORES: Estomia; Processo de enfermagem; Terminologia; Estomaterapia.

\section{RESUMEN}

Objetivos: Construir, con base en la Clasificación Internacional para la Práctica de Enfermería (CIPE®), enunciados de diagnósticos/ resultados e intervenciones de enfermería en el cuidado de las personas con estoma de eliminación intestinal y confirmar, con especialistas, la pertinencia y la importancia de los enunciados elaborados. Métodos: Encuesta metodológica desarrollada en el periodo de septiembre de 2016 a enero de 2017, en la cual se elaboraron enunciados de diagnósticos/resultados de enfermería negativos, positivos, de riesgo y de probabilidades y enunciados de intervenciones para cada diagnóstico/resultado. Los diagnósticos/resultados e intervenciones elaborados fueron mapeados con la CIPE@ versión 2015, dando como resultados enunciados constantes y no constantes de la clasificación. Los enunciados elaborados y mapeados fueron sometidos al proceso de confirmación de pertinencia e importancia por 10 especialistas, por medio de cuestionario virtual y análisis de los datos por el método de porcentaje de concordancia. Resultados: Fueron elaborados 110 diagnósticos/resultados de enfermería, de los cuales 78 (70,9\%) fueron confirmados por los especialistas y 119 intervenciones de enfermería, de las cuales 103 (86,5\%) fueron confirmadas. Conclusión: La elaboración de enunciados de diagnósticos/ resultados e intervenciones de enfermería y el proceso de confirmación de pertinencia e importancia por especialistas ayudaron en la búsqueda de evidencias de elementos de la práctica de enfermería dirigida al público específico.

DESCRIPTORES: Estomía; Estoma; Proceso de enfermería; Terminología; Estomaterapia.

\section{INTRODUCTION}

Intestinal elimination stoma refers to the exteriorization of a portion of the bowel through the abdominal wall and implies the person a new condition of life, since it changes its anatomy and physiological functions ${ }^{1}$. The main goal to be achieved in the health care of this person is rehabilitation, which aims to promote its autonomy and social reintegration ${ }^{2}$. In this context, nursing has an important role, engaging in actions related to the physical, psychological and social aspects of this clientele ${ }^{3}$.

In the scope of nursing care to the person with intestinal elimination stoma, the necessity to systematize nursing care to these clients stands out ${ }^{4}$. To this end, it is important to use nursing terminologies to identify and documenttation of specific nursing diagnoses, outcomes, and interventions.

Among the different terminologies of nursing, the International Classification of Nursing Practice (ICNP $\left.{ }^{\circledR}\right)$, developed by the International Council of Nurses (ICN), is a standardized terminology that allows the collection, description and systematic documentation of the elements of nursing practice ${ }^{5}$.

It is noticed an incipience of publications, in the scientific literature, that approach the standardization of nursing diagnoses, outcomes and interventions directed to the person with intestinal elimination stoma. Thus, this research presents as justification the necessity to bring nursing professionals closer to standardized terminologies, aiming at the systematized care of the specific clientele.

In this context, the objectives of this article were: to create, based on ICNP $®$, statements of nursing diagnoses/ outcomes and interventions for the person with intestinal elimination stoma and to confirm, with specialists, the pertinence and relevance of the created statements. 


\section{METHOD}

This is a methodological research based on the brazilian method for the development of terminological subsets of ICNP ${ }^{6}$, approved by the Research Ethics Committee by Lauro Wanderley University Hospital of the Federal University of Paraiba, under the opinion 961.402/2015.

Negative, positive, risk and chance nursing diagnoses/ outcomes statements and statements of nursing interventions were created for each diagnosis/ outcome for the person with intestinal elimination stoma. The creation of statements occurred from the combination of terms identified in the literature and in medical records ${ }^{7}$, obeying the ICN guidelines to ISO 18104:2014 ${ }^{8}$. Next, the nursing diagnoses/ outcomes and interventions created were mapped with ICNP® version $2015^{9}$, resulting in constant and non-constant statements of the classification.

The statements created and mapped were submitted to a process of confirmation of pertinence and relevance by specialists - nurses who have: specialist qualification, master or doctor in the area of health; experience with nursing diagnoses; and experience in care for people with intestinal elimination stoma in care, teaching and/or research.

The recruitment of the specialists to confirm the pertinence and relevance of the statements occurred from two means: intentional sampling, which was the search for authors of scientific articles on care of the person with intestinal elimination stoma; and snowball technique, which consists of a form of sampling in which one contact indicates another that meets the criteria established by the study to participate in the research ${ }^{10}$.

In both the intentional sampling and the snowball technique, the data of the specialists were searched in the curriculum registered in the Lattes Platform of the National Council of Scientific and Technological Development (CNPq), in order to observe the inclusion criteria - specialist qualification, master or doctor in the area of health; experience with nursing diagnoses; and experience in caring for people with intestinal elimination stoma in care, teaching and/or research. Those who met the criteria were contacted via e-mail, when it found the e-mail addresses, and were invited to participate in the survey.

The population was composed of the total number of specialists invited to participate in the research, represented by 71 nurses distributed in different brazilian states. The invitation to specialists throughout the national territory occurred solely with the purpose of capturing the largest possible number of participants for the confirmation of pertinence and relevance. Therefore, this research did not consider relevant to analyze data referring to the naturalness or regionality of the participants.

Data collection occurred between September 2016 and January 2017. The sample was defined by the number of nurses who completed the data collection instrument, represented by 10 specialists. The total completion of the instrument was necessary, since incomplete filling could mean withdrawal of participation.

The data collection instrument consisted of two online questionnaires, sent by means of an Acceptance Free and Informed Consent Form - one to evaluate the negative nursing diagnoses and its respective nursing interventions and the other to evaluate the positive nursing diagnoses, risk and chance and its respective nursing interventions. Two questionnaires were chosen in order to avoid to overload the specialists, due to the large number of statements submitted to the process of confirmation of pertinence and relevance.

The data collected from the questionnaires were analyzed using the percentage agreement method: number of participants who agreed divided by the total number of participants and multiplied by 100 , being confirmed the statements that obtained degree of agreement greater or equal to $80 \%{ }^{11}$.

\section{RESULTS}

A total of 110 nursing diagnoses/ outcomes statements were created for the person with intestinal elimination stoma, of which 41 (37.3\%) are ICNP ${ }^{\circledR}$ constants and 69 (62.7\%) are not included in the classification, and 119 statements of nursing interventions, of which six (5\%) are constant and 113 (95\%) are not included in the classification.

Examples of nursing diagnoses/ outcomes created constant in ICNP ${ }^{\circledR}$ are: low self-esteem; complication of the stoma; peristome skin complication; impaired spiritual condition; impaired psychological condition; self-care deficit; confrontation trouble; social isolation; positive self-esteem; capable of performing self-care; able to socialize; effective confrontation; positive body image; risk of complications 
of the stoma; risk of psychosocial condition, impaired; and risk of depressed mood.

The nursing interventions created constant in ICNP® are: guidance on complications of the stoma; guide on peristome skin complications; guide about care with the stoma; orienting about physical exercise; provide emotional support; and provide spiritual support.
Of the 110 nursing diagnoses/ outcomes created, 78 (70.9\%) were confirmed by the specialists, and of the 119 interventions created, 103 (86.5\%) were confirmed.

Table 1 presents examples of nursing diagnoses/ outcomes and interventions statements for the person with specialist confirmed intestinal elimination stoma.

Table 1. Examples of nursing diagnoses/ outcomes and interventions statements for the person with intestinal elimination stoma confirmed by specialists. João Pessoa, Paraíba, Brazil, 2017.

\section{Nursing Diagnoses}

Retention of the stoma

Peristome dermatitis

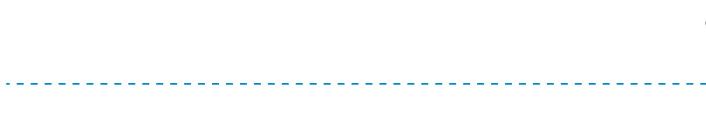

Social isolation

Soch

Impaired family process

Confrontation trouble

Impaired sexual process

Self-care deficit

Positive self-esteem

Effective spiritual condition

Able to perform self-care

Risk of complications of the stoma

Chance for intestinal elimination control by

colostomy

\section{Nursing interventions}

Refer to surgeon for non-functioning stoma; guide about care with the stoma; guide about complications of the stoma; guide the choice of suitable collector equipment and adjuvants; check the possibility of the customer to acquire convex adhesive base plate (board) equipment

Guidance on peristome skin care; orient on hygiene of the peristome skin with warm water and neutral soap; orient on drying of the peristome skin with clean and soft cloth; guide the choice of suitable collector equipment and adjuvants; explain about the different collector equipment and adjuvants available in the market

Guide for clothings that provide safety and comfort; encourage leisure activities; advice on the ingestion of food and liquids that prevent excessive formation of gases

Encourage communication with the family; explain to the family the importance of participating in the confrontation process; to guide the family about care with the stoma and peristome skin; explain to the family the importance of self-care

for client independence; encouraging the family to encourage self-care Encourage participation in support groups; encourage communication with the family; to encourage the search for understanding of the new condition of life; encourage the search for strategies to adapt to the new condition of

life; encourage the search for acceptance through spirituality

Encourage communication with partner; encourage pursuit of strategies that provide sexual satisfaction; explain the importance of avoiding abdominal effort to avoid complications of the stoma; advise on the ingestion of food

and liquids to avoid excessive formation of gases; guidance on sexual dysfunction caused by rectal amputation surgery

Obtain data on abilities (or skills) to perform self-care; guiding about selfcare with the stoma and peristome skin; explain the importance of self-care for independence; encouraging the family to encourage self-care; guide the choice of suitable collector equipment and adjuvants; to guide clothing that provides safety and comfort

Support the search for positive elements about yourself; reinforce positive self-esteem

Support spiritual well-being; strengthen pursuit by faith according to spiritual belief.

Strengthen abilities (or skills) to perform self-care; strengthen guidelines on self-care with the stoma and peristome skin; reinforce the importance of self-care for independence; guidelines on complications of the stoma and peristome skin

Guidance on care with the stoma; guide about complications of the stoma; guidance on the choice of suitable collector equipment and adjuvants Explain colostomy irrigation technique; guiding about colostomy autoirrigation 


\section{DISCUSSION}

In view of the results of the mapping between the nursing diagnoses/ outcomes and interventions in the care of the person with intestinal elimination stoma and $\mathrm{ICNP} \otimes$, it was observed that there were predominance of statements not included in the classification, which reflects the necessity for ICNP ${ }^{\circledR}$ updates with the purpose of embracing concepts capable of representing the problems or potentialities of the person with intestinal elimination stoma and the nursing actions to the specific clientele. Furthermore, the importance of developing a terminological subset of ICNP ${ }^{\circ}$ directed to this group of clients is reinforced, since the subgroups, because it approach the elements of nursing practice for a given area of professional practice, consist of technological strategies that support the systematization of nursing care for specific clientele, adapting to the world language ${ }^{12}$.

The confirmation of $70.9 \%$ of the nursing diagnoses/ outcomes and $86.5 \%$ of the nursing interventions directed to the person with intestinal elimination stoma revealed the pertinence and relevance of the statements created based on a standardized terminology in the context of directed care to this clientele. Since the questionnaires did not have the field to justify the answers, it was not possible to determine what motivated the specialists to confirm or not the statements, which is one of the limitations of this study.

In the literature on care of the person with intestinal elimination stoma, nursing diagnoses based on $\mathrm{ICNP}{ }^{\circledR}$ have been found to corroborate statements that have been confirmed by specialists, such as "impaired skin integrity", "risk of impaired skin integrity"; "adequate skin integrity"; "sexual impotence"; "decreased sexual relation"; "adequate sexual relation"; "ability to perform impaired self-care"; "ability to perform adequate selfcare"; "risk of ability to perform impaired self-care"; "impaired ability to manage stoma care"; "effective ability to manage stoma care"; "risk of diarrhea"; and "risk of constipation".

It should be noted that, in addition to ICNP $®$, other terminologies allow the identification of nursing diagnoses related to the person with intestinal elimination stoma. Among these, the diagnoses of NANDA International Inc. (NANDA-I) meet the statements confirmed by specialists in this research: "poor knowledge"; "effective control of the therapeutic rule"; and "impaired social interaction" ${ }^{\prime 3}$.

Despite efforts to state the needs of people with intestinal elimination stoma and specific actions for this clientele in a standardized manner, there are still few studies that present diagnoses/ outcomes and interventions based on nursing terminologies, explore the experience, identify the needs ${ }^{14-16}$ and describe the specific nursing care ${ }^{17-19}$. Thus, it was verified that the phenomena, demands and actions of the person with intestinal elimination stoma are discussed in the literature, but it is urgent the necessity to standardize statements that represent them, in order to systematize the nursing care to this clientele.

Among the nursing diagnoses/ outcomes in the care of the person with intestinal elimination stoma not confirmed by the specialists, "low self-esteem" "negative body image" and "negative self-image" stood out. This discovery was an unexpected result, given that the literature on the subject shows that the decrease in self-esteem and changes in body image or self-image are phenomena that considerably affect these individuals $\mathrm{s}^{20,21}$ and points out the importance of nurses' to achieve rehabilitation ${ }^{22}$.

Also, the diagnoses "decreased self-esteem" based on ICNP ${ }^{23}$ and "body image disorder" of NANDA-I ${ }^{13}$ were found in the literature for the person with intestinal elimination stoma. It is also arguable that the statements "positive self-esteem," "positive body image," "positive self-image," "low self-esteem risk," "negative body image risk," and "negative self-image risk." The divergence between the evaluations of the statements may have occurred because the specialists who evaluated the negative diagnoses were different from those who evaluated the positive, risk and chance diagnoses. In this case, the choice of two groups of specialists may have proved to be a limitation of this study.

\section{CONCLUSION}

It is believed that the creation of nursing diagnosis/ outcomes and interventions statements for the person 
with intestinal elimination stoma and the process of confirmation of pertinence and relevance by specialists helped in the search for evidences of elements of the practice of nursing directed to the specific clientele, as well as subsidize the development of a terminological subset of ICNP ${ }^{\circledR}$ for the self-care of the person with intestinal elimination stoma.

The limitations of the study include the difficulty of nurses adhering to the process of confirming the pertinence and relevance of the statements, the lack of field to justify the answers of the specialists in the instrument of data collection and the establishment of two groups of specialists during the process of confirmation of relevance and relevance.

The proposal of a terminological subset of ICNP ${ }^{\circledR}$ for the self-care of the person with intestinal elimination stoma may contribute to the standardization of the nursing language directed to the care of the specific clientele, facilitating the communication and the sharing of information among the professionals, reflecting in the systematization of care, as well as in the visibility of nursing.

\section{AUTHOR'S CONTRIBUTION}

Conceptualization, Carvalho CMG; Cubas MR and Nobrega MML; Methodology, Carvalho CMG; Cubas MR and Nobrega MML; Investigation, Carvalho CMG; Writing - First version, Carvalho CMG; Cubas MR and Nobrega MML; Writing - Review \& Editing, Carvalho CMG; Cubas MR and Nobrega MML; Supervision, Cubas MR and Nobrega MML.

\section{REFERENCES}

1. Sene LL, Oliveira WT. Sentimentos e percepções de pessoas ostomizadas. Rev Uningá. 2016;47(2):51-5.

2. Sasaki VDM, Teles AAS, Lima MS, Barbosa JCC, Lisboa BB, Sonobe HM. Reabilitação de pessoas com estomia intestinal: revisão integrativa. Rev enferm UFPE Online. 2017;11(Supl. 4):1745-54. doi: 10.5205/reuol.10438-930701-RV.1104sup201717.

3. Medeiros LP, Silva IP, Lucena SKP, Sena JF, Mesquita EKS, Oliveira DMS, Costa IKF. Atividades da intervenção de enfermagem "cuidados com a ostomia". Rev enferm UFPE Online. 2017;11(Supl. 12): 5417-26.

4. Silva ES, Castro DS, Garcia TR, Romero WG, Primo CC. Tecnologia do cuidado à pessoa com colostomia: diagnósticos e intervenções de enfermagem. REME. 2016;20(931). doi: 10.5935/1415-2762.20160001.

5. Conselho Internacional de Enfermeiros. Classificação Internacional para a Prática de Enfermagem CIPE®: versão 2017. Porto Alegre: Artmed; 2017.

6. Nóbrega MML, Cubas MR, Egry EY, Nogueira LGF, Carvalho CMG, Albuquerque LM. Desenvolvimento de subconjuntos terminológicos da CIPE® no Brasil. In: Cubas MR, Nóbrega MML. Atenção primária em saúde: diagnósticos, resultados e intervenções. Rio de Janeiro: Elsevier; 2015.

7. Carvalho CMG, Cubas MR, Nóbrega MML. Termos da linguagem especializada de enfermagem para o cuidado à pessoa ostomizada. Rev Bras Enferm. 2017;70(3):461-7. doi: 10.1590/0034-7167-2015-0058.

8. International Organization for Standardization. ISO 18104:2014: Health informatics - Categorial structures for representation of nursing diagnoses and nursing actions in terminological systems. Genebra: ISO; 2014.

9. Conselho Internacional de Enfermeiros. Classificação Internacional para a Prática de Enfermagem CIPE®: versão 2015. Porto Alegre: Artmed; 2016.
10. Vinuto J. A amostragem em bola de neve na pesquisa qualitativa: um debate em aberto. Temáticas. 2014;22 (44):203-20.

11. Alexandre NMC, Coluci MZ. O. Validade de conteúdo nos processos de construção e adaptação de instrumentos de medidas. Ciênc saúde coletiva. 2011;16(7):3061-8. doi: 10.1590/S1413-81232011000800006.

12. Clares JWB, de Freitas MC, Guedes MVC. Percurso metodológico para elaboração de subconjuntos terminológicos CIPE®: revisão integrativa. Rev Esc Enferm USP. 2014;48(6):1119-26 doi: 10.1590/S0080-62342014 0000700021.

13. Sampaio FAA, Aquino PS, Araújo TL, Galvão MTG. Assistência de enfermagem a paciente com colostomia: aplicação da teoria de Orem. Acta Paul Enferm. 2008;21(1):94-100. doi: 10.1590/S0103-21002008000100015.

14. Ribeiro CO, Muniz RM, Furtado SMSR, Viegas AC, Amaral DED. Descobrindo o mundo estomizado: vivência das pessoas com o dispositivo. ESTIMA, Braz. J. Enterostomal Ther. 2015;13(1):3-10. doi: 10.5327/Z1806-31442015000 10003.

15. Mota MS, Gomes GC, Petuco VM. Repercussões no processo de viver da pessoa com estoma. Texto Contexto Enferm. 2016;25(1). doi: 10.1590/0104-070720160001260014.

16. Freire DA, Angelim RCM, Souza NR, Brandão BMGM, Torres KMS, Serrano SQ. Autoimagem e autocuidado na vivência de pacientes estomizados: o olhar da enfermagem. Rev Min Enferm. 2017;21:e1019. doi: 10.5935/1415-2762.2017 0029.

17. Azevedo C, Faleiro JC, Ferreira MA, Oliveira SP, Mata LRF, Carvalho EC. Intervenções de enfermagem para alta de paciente com estomia intestinal: revisão integrativa. Rev Cubana Enfermer. 2014;30(2). 
18. Jesus BC, Ramos GF, Silva CCR, Gomes VCO, Silva EP. Prevenindo e tratando lesões peri-estoma. Cientefico. 2014;14(29)

19. Braz DS, Araujo RA, Trandafilov AZ. A importância das orientações de enfermagem para pacientes portadores de ostomia. Pesq e Ação. 2017;3(1).

20. Cardoso DBR, Almeida CE, Santana ME, Carvalho DS, Sonobe HM, Sawada NO. Sexualidade de pessoas com estomias intestinais. Rev Rene. 2015;16(4):576-85. doi: 10.15253/2175-6783.2015000400015.
21. Ferreira EC, Barbosa MH, Sonobe HM, Barichello E. Autoestima e qualidade de vida relacionada à saúde de estomizados. Rev Bras Enferm. 2017;70(2):288-95. doi: 10.1590/0034-7167-2016-0161.

22. Mendes JOS, Leite MMAM, Batista MRFF. Sentimentos vivenciados pelo homem adulto colostomizado. R Interd. 2014;7(1):58-67.

23. Sampaio FMC. A auto-estima na pessoa portadora de ostomia de eliminação intestinal. Revista Portuguesa de Enfermagem de Saúde Mental. 2010;4:31-7. 